\title{
RESIKO TERJADINYA PENYAKIT AKIBAT KERJA PADA PERAWAT
}

\author{
Elisa Widywati \\ elisawidyawati10@gmail.com
}

\section{LATAR BELAKANG}

Setiap tempat kerja selalu mempunyai risiko kecelakaan dan penyakit akibat kerja. Untuk mencegah terjadinya kecelakaan dan penyakit akibat kerja maka di setiap perusahaan yang memiliki tenaga kerja lebih dari 100 orang dan memiliki risiko besar terhadap kecelakaan dan penyakit akibat kerja wajib menerapkan program Keselamatan dan Kesehatan Kerja (Permenaker No.5 Th. 1991). Bekerja dapat diartikan sebagai kegiatan/pekerjaan paling sedikit satu jam berturut-turut selama seminggu yang lalu dengan maksud untuk memperoleh atau membantu memperoleh pendapatan atau keuntungan.

Perawat merupakan petugas kesehatan dengan presentasi terbesar dan memegang peranan penting dalam pemberian pelayanan kesehatan. Dalam menjalankan tugasnya perawat berisiko mengalami gangguan kesehatan dan keselamatan kerja (K3). Dari beberapa komponen pelayanan kesehatan di rumah sakit, perawat adalah salah satu tenaga pelayanan kesehatan yang berinteraksi dengan pasien yang intensitasnya paling tinggi dibandingkan dengan komponen lainnya. Setiap hari perawat tidak pernah jauh dan selalu berinteraksi dengan pasien. Hal tersebut yang membuat perawat selalu berhadapan langsung dengan bahaya dan dapat mengancam kesehatan dan keselamatan kerja perawat itu sendiri. Kecelakaan kerja pada perawat ini menimbulkan kerugian bagi perawat itu sendiri maupun pihak rumah sakit.

Perawat adalah tenaga kesehatan yang paling besar jumlahnya dan paling lama kontak dengan pasien, sehingga sangat berisiko dengan pekerjaannya. Sebagai salah satu jenis tenaga kesehatan, profesi perawat gigi tidak lepas dari berbagai faktor risiko yang memungkinkan terjadinya penyakit yang diakibatkan maupun yang berhubungan dengan pekerjaan yang menimbulkan bahaya terhadap kesehatan kerja (Health Hazard) maupun bahaya keselamatan 
kerja (Safety Hazard) yang dapat berakibat terjadinya kecelakaan yang dapat menyebabkan kecacatan atau kematian.

Kecelakaan adalah kejadian tidak terduga yang disebabkan oleh tindakan tidak aman dan kondisi tidak aman.Sebagian besar (85\%) kecelakaan disebabkan oleh faktor manusia dengan tindakan yang tidak aman. Tindakan tidak aman adalah tindakan yang dapat membahayakan pekerja itu sendiri maupun orang lain yang dapat menyebabkan terjadinya kecelakaan yang dapat disebabkan oleh berbagai hal seperti tidak memakai APD, tidak mengikuti prosedur kerja, tidak mengikuti peraturan keselamatan kerja dan bekerja tidak hati-hati.

\section{METODE}

Resiko terjaadinya peyankit akibat kerja pada perawat di rumah sakit, yakni teknik pengumpulan data dari berbagai sumber seperti textbook dan jurnal untuk mendapatkan data dan informasi yang lengkap dengan cara menyimpulkan dari 10 jurnal dengan tahun paling tua 2012. Dengan mencari dari berbagai jurnal maupun textbook dapat mudah dipahami dan dimengerti serta menyimpulkan nya dengan bahasa sendiri tanpa harus meniru karya orang lain.

\section{HASIL}

Tenaga keperawatan adalah salah satu tenaga pelayanan kesehatan yang paling sering berinteraksi dengan pasien dibandingkan dengan komponen lainnya seperti: dokter, teknisi, petugas farmasi, petugas laboratorium dan petugas kebersihan. Dari beberapa komponen tersebut, faktor risiko paling tinggi sebagai media terjadinya penyebaran infeksi kepada pasien adalah tenaga keperawatan.

Penyakit karena kerja adalah seuatu kendala pada tingkat keamanan dalam kerja, dalam perihal ini memerlukan usaha pencegahan, baik untuk keselamatan ataupun kesehatan beberapa pekerja yang berada di lingkungan rumah sakit. Penyakit karena kerja atau terkait dengan pekerjaan bisa dikarenakan oleh pemajanan di lingkungan kerja dengan terus menerus setiap hari. Untuk menghadapi perihal ini, maka langkah awal yang terpenting ialah 
pengenalan/identifikasi bahaya yang dapat muncul serta dievaluasi, lalu dikerjakan usaha pengendalian lewat cara melihat serta mengenal (walk through inspections).

Perawat termasuk kelompok tenaga kesehatan yang masuk dalam kelompok rentan tertular (vulnerable people) serta menjadi kelompok berisiko atau rawan tertular karena setiap hari perawat kontak langsung dengan pasien dalam waktu cukup lama, kurang lebih 6-8 jam per hari, sehingga selalu terpajan mikroorganisme penyebab penyakit. Bahaya biologi dapat disebabkan karena terdapat organisme penyebab penyakit pada tempat kerja atau zat yang dihasilkan dari mikroorganisme yang mengancam kesehatan manusia. Penularan bahaya biologi yang tinggi merupakan indikator pentingnya suatu usaha pengendalian infeksi. WHO telah menetapkan pentingnya penerapan standard precaution pada petugas kesehatan dalam setiap tindakan untuk mencegah peningkatan infeksi. Kewaspadaan standar (standard precaution) adalah kewaspadaan untuk mencegah penyebaran penyakit menular yang diatur menurut pedoman kewaspadaan isolasi oleh CDC dan HICPAC.

\section{PEMBAHASAN}

Penyakit karena kerja adalah seuatu kendala pada tingkat keamanan dalam kerja, dalam perihal ini memerlukan usaha pencegahan, baik untuk keselamatan ataupun kesehatan beberapa pekerja yang berada di lingkungan rumah sakit. Penyakit karena kerja atau terkait dengan

pekerjaan bisa dikarenakan oleh pemajanan di lingkungan kerja dengan terus menerus setiap hari. Untuk menghadapi perihal ini, maka langkah awal yang terpenting ialah pengenalan/identifikasi bahaya yang dapat muncul serta dievaluasi, lalu dikerjakan usaha pengendalian lewat cara melihat serta mengenal (walk through inspections).

Penyakit Akibat Kerja adalah penyakit yang disebabkan oleh pekerjaan dan lingkungan kerja. Faktor risiko PAK antara lain: Golongan fisik, kimiawi, biologis atau psikososial di tempat kerja. Faktor tersebut di dalam lingkungan kerja merupakan penyebab yang pokok dan menentukan terjadinya penyakit akibat kerja. Faktor lain seperti kerentanan individual juga berperan dalam perkembangan penyakit di antara pekerja yang terpajan. 
Kecelakaan adalah kejadian tidak terduga yang disebabkan oleh tindakan tidak aman dan kondisi tidak aman.Sebagian besar (85\%) kecelakaan disebabkan oleh faktor manusia dengan tindakan yang tidak aman. Penyakit karena kerja serta kecelakaan kerja dikalangan petugas kesehatan serta non kesehatan di lingkungan rumah sakit belumlah terselesaikan dengan baik, hingga berlangsung kecenderungan penambahan prevalensi. Dalam perihal ini perlu mendapatkan perhatian, sebab seseorang yang bekerja bila mengalami kecelakaan atau penyakit karena kerja tidak hanya punya pengaruh pada diri sendiri, tapi ikut produktifitas kerja mengalami penurunan dalam pemberian service kesehatan yang optimal pada pasien. Kemungkinan petugas rumah sakit pada gangguan kesehatan serta kecelakaan kerja biasanya dikarenakan oleh perilaku petugas dalam kepatuhan melakukan tiap-tiap mekanisme pada kewaspadaan.

Faktor-fakor pemicu penyakit akibat kerja dapat dibedakan sebagai berikut:

a) Faktor Fisik, yang meliputi:

$>$ Suara tinggi/bising yang dapat menyebabkan ketulian.

$>$ Temperatur/suhu tinggi yang dapat menyebabkan Hyperpireksi, Milliaria, heat Cramp, Heat Exhaustion, Heart Stroke.

> Radiasi sinar elektromagnetik, pada mata infra merah dapat menyebabkan katarak, ultraviolet menyebabkan konjungtivitis, radioaktif/ alfa/ beta/ gama/ X menyebabkan gangguan terhadap sel tubuh manusia.

$>$ Tekanan udara tinggi yang dapat menyebabkan Coison Disease.

$>$ Getaran/vibration yang dapat menyebabkan Reynaud's Disease, Gangguan proses metabolisme, Polineurutis.

b) Faktor Kimia

$>$ Berasal dari bahan baku, bahan tambahan, hasil antara, hasil samping, hasil (produk), sisa produksi atau bahan buangan yang dapat berbentuk zat padat, cair, gas, uap maupun partikel. Materi ini masuk ke tubuh dapat melalui saluran pernafasan, saluran pencernaan, kulit dan mukosa.

$>$ Efek terhadap tubuh dapat menyebabkan iritasi, alergi, korosif, Asphyxia, keracunan sistemik, kanker, kerusakan/kelainan janin, pneumoconiosis, efek bius (narkose) dan pengaruh genetik. 
c) Faktor biologi yang dapat berasal dari virus, bakteri, parasit, jamur, serangga, binatang buas, dan lain-lain.

d) Faktor Ergonomi/Fisiologi

$>$ Penyebabnya adalah cara kerja, posisi kerja, alat kerja, lingkungan kerja yang salah dan kontruksi salah.

Efek terhadap tubuh yaitu dapat menyebabkan kelelahan fisik, nyeri otot, deformitas tulang, perubahan bentuk dan dislokasi

e) Faktor Mental/Psikologi

$>$ Penyebabnya yaitu suasana kerja monoton dan tidak nyaman, hubungan kerja kurang baik, upah kerja kurang, terpencil, atau tak sesuai bakat yang mengakibatkan stress.

Risiko utama akibat kerja pada perawat adalah penyakit menular, cedera otot dan tulang, gangguan tidur.

1. Penyakit menular Tenaga perawat kemungkinan melakukan kontak yang berhubungan dengan cairan darah berkuman, cairan tubuh, busa, cairan mulut, cairan urine, kotoran manusia, muntahan dan lainlain sehingga mendapat penularan.

Media penularan :

- Penularan melalui cairan darah

- Penularan melalui udara atau busa

- Penularan melalui kontak tubuh

- Penularan melalui mulut -(berkontak dengan cairan urine dan kotoran manusia)

Penyakit menular : Hepatitis B, hepatitis C, AIDS, Flu menular, TBC, SARS, Penyakit kulit biasa, radang infeksi kulitRadang infeksi perut, hepatitis A.

2. Sakit otot dan tulang Tindakan memindahkan pasien, membalikkan dan menepuknepuk punggung pasien, latihan penyembuhan, dikarenakan sering mengeluarkan tenaga berlebihan, gerakan yang tidak benar atau berulang-ulang, mudah menyebabkan cedera di bagian otot dan tulang, apabila tenaga perawat berusia agak tua, maka akan menambah resiko dan tingkat keseriusan cedera di otot dan tulang. 
3. Gangguan tidur Tenaga perawat perlu waktu sepanjang malam atau waktu yang tidak tentu untuk menjaga pasien, sehingga mudah mengalami kondisi tidur pendek, tidur kurang lelap, kesulitan tidur.

Upaya yang dapat dilakukan oleh perusahaan untuk mencegah PAK adalah sebagai berikut:

1. Menyingkirkan atau mengurangi risiko pada sumbernya, misalnya menggantikan bahan kimia yang berbahaya dengan bahan yang tidak berbahaya.

2. Mengurangi risiko dengan pengaturan mesin atau menggunakan APD.

3. Menetapkan prosedur kerja secara aman untuk mengurangi risiko lebih lanjut.

4. Menyediakan, memakai dan merawat APD

\section{PENUTUP}

Perawat termasuk kelompok tenaga kesehatan yang masuk dalam kelompok rentan tertular (vulnerable people) serta menjadi kelompok berisiko atau rawan tertular karena setiap hari perawat kontak langsung dengan pasien dalam waktu cukup lama, kurang lebih 6-8 jam per hari, sehingga selalu terpajan mikroorganisme penyebab penyakit. Bahaya biologi dapat disebabkan karena terdapat organisme penyebab penyakit pada tempat kerja atau zat yang dihasilkan dari mikroorganisme yang mengancam kesehatan manusia.

Penyakit karena kerja adalah seuatu kendala pada tingkat keamanan dalam kerja, dalam perihal ini memerlukan usaha pencegahan, baik untuk keselamatan ataupun kesehatan beberapa pekerja yang berada di lingkungan rumah sakit. Penyakit Akibat Kerja adalah penyakit yang disebabkan oleh pekerjaan dan lingkungan kerja. Faktor risiko PAK antara lain: Golongan fisik, kimiawi, biologis atau psikososial di tempat kerja. Faktor tersebut di dalam lingkungan kerja merupakan penyebab yang pokok dan menentukan terjadinya penyakit akibat kerja. Faktor lain seperti kerentanan individual juga berperan dalam perkembangan penyakit di antara pekerja yang terpajan. 


\section{DAFTAR PUSTAKA}

Akbar, M Agung. (2019). Buku Ajar Konsep-Konsep Dasar dalam Keperawatan Komunitas. Deepublish. Yogyakarta.

Ardenny.(2015).Faktor Yang Berhubungan Dengan Kecelakaan Kerja Pada Perawat Di Rumah Sakit Jiwa. Jurnal Proteksi Kesehatan, 4, 1-6.

Depkes RI. (2013). Pedoman Pelaksanaan Kewaspadaan Universal Di Pelayanan Kesehatan. Depkes RI. Jakarta

Iwan M. Ramdan, Abd. Rahman.(2017). Analisis Risiko Kesehatan dan Keselamatan Kerja (K3) pada Perawat. JKP .5(3)

Maria, Silvia., Joko Wiyono., \& Erlisa Candrawati. (2015). Kejadian Kecelakaan Kerja Perawat Berdasarkan Tindakan Tidak Aman. Jurnal Care, 3(2), 9-17.

Nur Azizah, Setiawan2, Gerry Silaban.(2018) .Hubungan Antara Pengawasan,Prosedur Kerja dan Kondisi Fisik Dengan Terjadinya Kecelakaan Pada Perawat Di Ruang Inap Sakit Permata Bunga Medan. Jurnal JUMANTIK Vol.3 (2)

Nursalam. 2014. Manajemen Keperawatan, Aplikasi dalam Praktik Keperawatan Profesional. Edisi 4. Salemba Medika. Jakarta.

Salawati,L. (2015). Penyakit Akibat Kerja Dan Pencegahan. Jurnal Kedokteran Syiah Kuala,15 (2).

Simamora, R. H. (2017). A strengthening of role of health cadres in BTA-Positive Tuberculosis (TB) case invention through education with module development and video approaches in Medan Padang bulan Comunity Health Center, North Sumatera Indonesia. International Journal of Applied Engineering Research, 12(20), 10026-10035. 
Simamora, R. H., \& Saragih, E. (2019). Penyuluhan kesehatan terhadap masyarakat: Perawatan penderita asam urat dengan media audiovisual. JPPM (Jurnal Pendidikan dan Pemberdayaan Masyarakat), 6(1), 24-31.

Suarniti, Luh Putu. (2015). Risiko Ergonomi Penyakit Akibat Kerja Pada Perawat Gigi. Jurnal Kesehatan Gigi, 3(2), 113-123.

Tukatman, et. al. (2015). Analisis Keselamatan Dan Kesehatan Kerja Perawat Dalam

Penanganan Pasien Di Rumah Sakit Benyamin Guluh Kabupaten Kolaka. Jurnal Ners, 10(2), 343-347. 